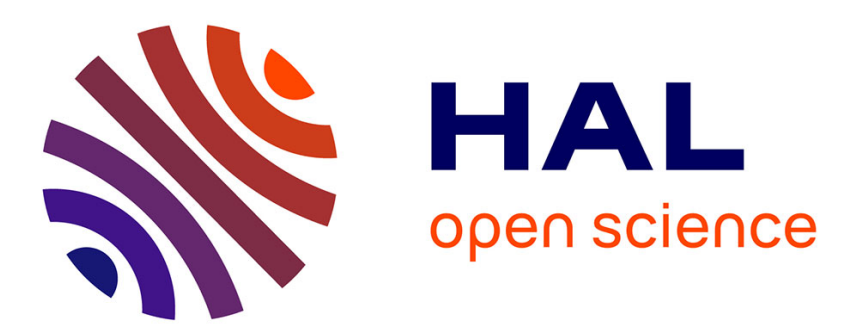

\title{
Characterization of a single prolactin (PRL) receptor in Tilapia (Oreochromis niloticus) which binds both PRL1 and PRL2
}

\author{
Benoît Aupérin, F. Rentier-Delrue, J.A. Martial, Patrick Prunet
}

\section{To cite this version:}

Benoît Aupérin, F. Rentier-Delrue, J.A. Martial, Patrick Prunet. Characterization of a single prolactin (PRL) receptor in Tilapia (Oreochromis niloticus) which binds both PRL1 and PRL2. Journal of Molecular Endocrinology, 1994, 13, pp.241-251. 10.1677/jme.0.0130241 • hal-02713656

\section{HAL Id: hal-02713656 \\ https://hal.inrae.fr/hal-02713656}

Submitted on 1 Jun 2020

HAL is a multi-disciplinary open access archive for the deposit and dissemination of scientific research documents, whether they are published or not. The documents may come from teaching and research institutions in France or abroad, or from public or private research centers.
L'archive ouverte pluridisciplinaire HAL, est destinée au dépôt et à la diffusion de documents scientifiques de niveau recherche, publiés ou non, émanant des établissements d'enseignement et de recherche français ou étrangers, des laboratoires publics ou privés. 


\title{
Characterization of a single prolactin (PRL) receptor in tilapia (Oreochromis niloticus) which binds both $\mathrm{PRL}_{\mathrm{I}}$ and $\mathrm{PRL}_{\mathrm{II}}$
}

\author{
B Auperin, F Rentier-Delrue*, J A Martial* and P Prunet \\ Laboratoire de Physiologie des Poissons, INRA, Campus de Beaulieu, 35042 Rennes cédex, France \\ * Laboratoire de Biologie Moléculaire et de Génie Génétique, Institut de Chimie B6, Université de Liège, \\ B-4000 Sart Tilman, Belgium
}

(Requests for offprints should be addressed to P Prunet)

\begin{abstract}
In tilapia, there are two forms of prolactin (PRL) whose effects on sodium and chloride movements differ and depend on the living environment of the fish. To see whether different receptors or the same receptor mediates these different effects, we have characterized the specific binding of both forms of tilapia (ti)PRL in two osmoregulatory organs, the gill and kidney. Two recombinant tiPRLs were used for this analysis. The recombinant hormones had the same properties as the native hormones. in a tilapia gill radioreceptor assay. Specific binding to gill and kidney membranes was increased by optimizing the quality of the tissue preparations (physiological state of fish, membrane preparation)
\end{abstract}

and the incubation conditions ( $\mathrm{pH}$, salt concentrations, temperature, time). Under these optimized conditions, we detected only one class of high affinity $P R L$ receptor in gill and kidney. Its binding affinity was higher for tiPRL $L_{I}$ than for tiPRL ${ }_{I I}$ in both gill and kidney (for tiPRL, the respective affinity values were 2.9 and $2.3 \times 10^{10}$ per $M$, for tiPRL $_{11}$ they were 1.9 and $0.5 \times 10^{10}$ per $\mathrm{M}$ ). In competition studies, tiPRL $\mathrm{I}_{\mathrm{I}}$ was more potent, followed by tiPRL $L_{I I}$ and ovine (o)PRL. tiGH and oGH did not significantly displace either tiPRL. The receptor we have characterized thus recognizes quite specifically both tiPRLs.

Fournal of Molecular Endocrinology (1994) 13, 241-251

\section{INTRODUCTION}

Although in fish, prolactin (PRL) is pleiotropic and exhibits a spectrum of biological activities, its primary and most studied role in these animals is water and electrolyte homeostasis (for reviews see Clarke \& Bern, 1980; Hirano et al. 1986). In several fish species, nucleotide or polypeptide sequence analyses have revealed the existence of two distinct, albeit similar, genes. In tilapia, however, two quite different PRL molecules are synthesized and released from the pituitary: their sequence identity is only $69 \%$, one variant (tilapia (ti)PRL, 188 amino acids) being more similar to other fish PRLs than to the other variant (tiPRL $\mathrm{II}_{1}, 177$ amino acids) (Yamaguchi et al. 1988; Rentier-Delrue et al. 1989).

Recent studies of the osmoregulatory roles of tiPRL during adaptation to a hyperosmotic environment have revealed that the two tiPRL forms perform different biological functions; only tiPRL exerts a dose-related sodium-retaining effect in tilapia adapted to brackish water (Auperin et al. $1994 a$ ), whereas both tiPRL forms restore plasma $\mathrm{Na}^{+}$levels to normal in hypophysectomized fish kept in fresh water (Specker et al. 1985). In addition, tiPRL $L_{I I}$ is significantly less potent than tiPRL $L_{\mathrm{I}}$ in restoring plasma $\mathrm{Cl}^{-}$levels in such fish (B. Auperin, F. Rentier-Delrue, J. A. Martial \& P. Prunet, unpublished observations). These results lead to the interesting question of whether these different functions might be associated with different tiPRL receptor forms.

Attempts have been made to characterize tiPRL receptors in various tilapia organs using ovine (o)PRL (Edery et al. 1984; Dauder et al. 1990). The specific binding measured in osmoregulatory organs (gill and kidney) was low, however, and ${ }^{125} \mathrm{I}$ labelled oPRL could be significantly displaced from liver membranes by fish or mammalian growth hormone (GH) (Dauder et al. 1990; Prunet \& Auperin, 1994). As suggested by Dauder et al. (1990), it is possible that "both tiPRL and tiGH 
binding sites recognize mammalian PRL'. Since the interaction between mammalian PRL and fish receptors may produce artifacts, full characterization of PRL receptors in tilapia species requires the development of homologous radioreceptor assays using tiPRL $L_{1}$ and tiPRL $\mathrm{III}_{\mathrm{II}}$ as ligands.

We have developed such assays, thanks to the recent production of two recombinant tiPRL forms exhibiting full biological activity (Swennen et al. 1991; Auperin et al. 1994a). The aim of the present study was to fully characterize the tiPRL receptors. We have focused on the different osmoregulatory functions of the two tiPRI forms and have therefore characterized the PRL receptors mainly in two major osmoregulatory organs, the gill and kidney. We have revealed only one class of tiPRL receptor in these organs, to which tiPRL ${ }_{I}$ binds with a higher affinity than tiPRL $\mathrm{II}_{\mathrm{II}}$.

\section{MATERIALS AND METHODS}

\section{Hormones}

Recombinant tiPRL hormones were produced according to Rentier-Delrue et al. (1989). Recombinant tiGH was a gift from J. Smal (Eurogentec, Seraing, Belgium). Native tiPRLs (tiPRL 1 and tiPRL $_{\text {II }}$ ) were generously provided by Prof. H. A. Bern (Department of Integrative Biology, University of California, Berkeley, CA, U.S.A.). oGH (NIDDK-oGH-15) and oPRL (NIDDK-oPRL19) were gifts from the NIDDK and the National Hormone and Pituitary Program (Bethesda, MD, U.S.A.).

\section{Animals}

Tilapia specimens (Oreochromis niloticus) were obtained from IDESSA (Bouaké, Ivory Coast), weighing less than $100 \mathrm{mg}$. They were maintained at the Rennes laboratory in fresh water until reaching the desired weight $(30-100 \mathrm{~g})$.

Previous studies have shown that transfer to brackish water induces a significant increase in the number of free PRL receptors within $24 \mathrm{~h}$ (Auperin et al. 1994b). Thus, all tissues were collected from fish transferred to brackish water $(21 \%)$ and kept there for $36-48 \mathrm{~h}$.

\section{Membrane preparations}

Gills or kidneys were frozen in liquid nitrogen and stored at $-70^{\circ} \mathrm{C}$ before use. Frozen gills were homogenized in preparation buffer $(2.5 \mathrm{~mm}$ Tris$\mathrm{HCl}$ buffer, $\mathrm{pH} 7.5$, containing $1.5 \mathrm{~mm} \mathrm{MgCl}_{2}$,
$1.5 \mathrm{mM} \mathrm{CaCl}_{2}, 0.25 \mathrm{M}$ sucrose) plus $1 \mathrm{mM}$ phenylmethylsulphonyl fluoride (PMSF) $(7.5 \mathrm{ml} / \mathrm{g}$ frozen tissue) with an Ultraturrax homogenizer at maximal speed for 15 -s periods separated by intervals of a few minutes for cooling. The homogenate was layered over $10 \mathrm{ml}$ sucrose $(1 \mathrm{M})$ and centrifuged for $10 \mathrm{~min}$ at $400 \mathrm{~g}$ at $4^{\circ} \mathrm{C}$. The supernatant, without the interface, was layered over $5 \mathrm{ml}$ sucrose $(1.8 \mathrm{M})$ and centrifuged for $1 \mathrm{~h} 45 \mathrm{~min}$ at $120000 \mathrm{~g}$ and $4{ }^{\circ} \mathrm{C}$ in a zonal rotor. The interface between the $1.8 \mathrm{M}$ sucrose and the supernatant was collected, diluted with gill assay buffer $(2.5 \mathrm{~mm}$ Tris- $\mathrm{HCl}$ buffer, $\mathrm{pH}$ $7 \cdot 5$, containing $1.5 \mathrm{mM} \mathrm{MgCl} 2$ and $1.5 \mathrm{mM} \mathrm{CaCl}_{2}$ ) and centrifuged at $120000 \mathrm{~g}$ for $20 \mathrm{~min}$ at $4{ }^{\circ} \mathrm{C}$ in a zonal rotor. The pellet was resuspended with a glass homogenizer (Dounce $250 \mu \mathrm{m}$ ) in gill assay buffer with trypsin inhibitor $(0.05 \%, w / v)$ at a final concentration of $2 \mathrm{~g}$ initial tissue/ml. The membrane preparations were stored at $-30^{\circ} \mathrm{C}$ until assayed.

Frozen kidneys were homogenized in kidney assay buffer $(10 \mathrm{mM}$ Tris- $\mathrm{HCl}, 1.5 \mathrm{mM} \mathrm{MgCl}$ ) plus $1 \mathrm{~mm}$ PMSF. The amount of buffer added for this step was $5 \mathrm{ml} / \mathrm{g}$ frozen tissue. Homogenization was performed with an Ultraturrax homogenizer at maximal speed for two 10 -s periods, with an interval of a few minutes for cooling. The homogenate was sieved through cheesecloth and centrifuged for $30 \mathrm{~min}$ at $3200 \mathrm{~g}$ and $4{ }^{\circ} \mathrm{C}$. The pellet was resuspended with a glass homogenizer in assay buffer and recentrifuged under the same conditions. The pellet was then resuspended in assay buffer with $0.05 \%$ trypsin inhibitor at $2 \mathrm{~g}$ initial tissue $/ \mathrm{ml}$. The membrane preparations were stored at $-30^{\circ} \mathrm{C}$ until assayed.

Skin was prepared like gills; liver was prepared like kidney.

For the gill membrane preparations, the membrane protein concentration was determined by the method of Lowry et al. (1951) and was adjusted to approximatively $6 \mathrm{mg} / \mathrm{ml}$ (initial tissue concentration $2 \mathrm{~g} / \mathrm{ml}$ )

\section{Iodination of recombinant tiPRLs}

$\mathrm{Na}^{125} \mathrm{I}$ (specific activity $0.1 \mathrm{mCi} / \mu \mathrm{l}$ ) was purchased from Amersham (Les Ullis, France). The two tiPRLs were iodinated by the chloramine-T method (Greenwood et al. 1963; with modifications introduced by Martal, 1972). Radioiodinated tiPRL was separated from free ${ }^{125} \mathrm{I}^{-}$using a $30 \mathrm{~cm}$ gel filtration column (Fractogel TSK HW-55; Merck) previously equilibrated with $20 \mathrm{~mm}$ phosphate buffer, $0 \cdot 15 \mathrm{M} \mathrm{NaCl}, 1 \% \mathrm{BSA}, \mathrm{pH} 7 \cdot 5$. The specific activity of ${ }^{125}$ I-labelled tiPRL was $40-50 \mu \mathrm{Ci} / \mu \mathrm{g}$ PRL for both PRLs. 


\section{Receptor binding assays}

A membrane preparation $(100 \mu l)$ diluted in assay buffer plus one isoform of labelled tiPRL (800010000 c.p.m.) in $50 \mu \mathrm{l}$ assay buffer were incubated in duplicate with (non-specific binding) or without (total binding) $1 \mu \mathrm{g}$ tiPRL (final volume $250 \mu \mathrm{l}$ ). Assay tubes were rocked for $20-22 \mathrm{~h}$ at $12^{\circ} \mathrm{C}$. The assays were stopped by adding $2 \mathrm{ml}$ ice-cold assay buffer. The tubes were centrifuged for $30 \mathrm{~min}$ at $3200 \mathrm{~g}$ and the contents decanted. The bound radioactivity in the pellet was measured with a Packard Multiprias 2 counter. Specific binding (B) was calculated as the difference between total and non-specific binding and results are expressed as percentages of the total radioactivity ( $\mathrm{T}$ ) originally added to each tube $(\mathrm{B} / \mathrm{T} \times 100)$.

\section{Calculations}

The quality of the labelled hormone was analysed in membrane saturation experiments. In these experiments, $60 \%$ of the labelled tiPRL ${ }_{I}$ and $30 \%$ of the labelled tiPRL $\mathrm{II}_{1}$ were found to bind to the membrane. The calculated specific activities and amounts of hormone added to each tube were therefore corrected by these factors as described by Garnier (1980) for Scatchard analysis (Scatchard, 1949).

Saturation assay data are presented as Scatchard plots and analysed with the Ligand program in order to estimate the affinity constants ( $K_{\mathrm{a}}$ values) and binding capacities ( $B_{\max }$ values).

\section{Statistical methods}

Results are presented as means \pm S.E.M. Differences between the $K_{\mathrm{a}}$ and $\mathrm{B}_{\max }$ values calculated for the tiPRL $_{I}$ and tiPRL ${ }_{I}$ tracers were evaluated by Mann-Whitney analysis. A probability level of $<0.05$ was considered significant.

\section{RESULTS}

\section{Binding to different tissue preparations}

Gill and kidney exhibited considerable specific binding which was higher for ${ }^{125} \mathrm{I}$-labelled tiPRL than for ${ }^{125} \mathrm{I}$-labelled tiPRL $\mathrm{II}$. The skin and liver preparations exhibited low specific binding, the levels being the same for both labelled hormones (Fig. 1).

In gill and kidney membranes, tiPRL ${ }_{I}$ and tiPRL ${ }_{1 I}$ binding was fully characterized. The preparation and incubation conditions were optimized to ensure high specific tiPRL $\mathrm{I}_{\mathrm{I}}$ and tiPRL $\mathrm{I}_{\mathrm{I}}$ binding.

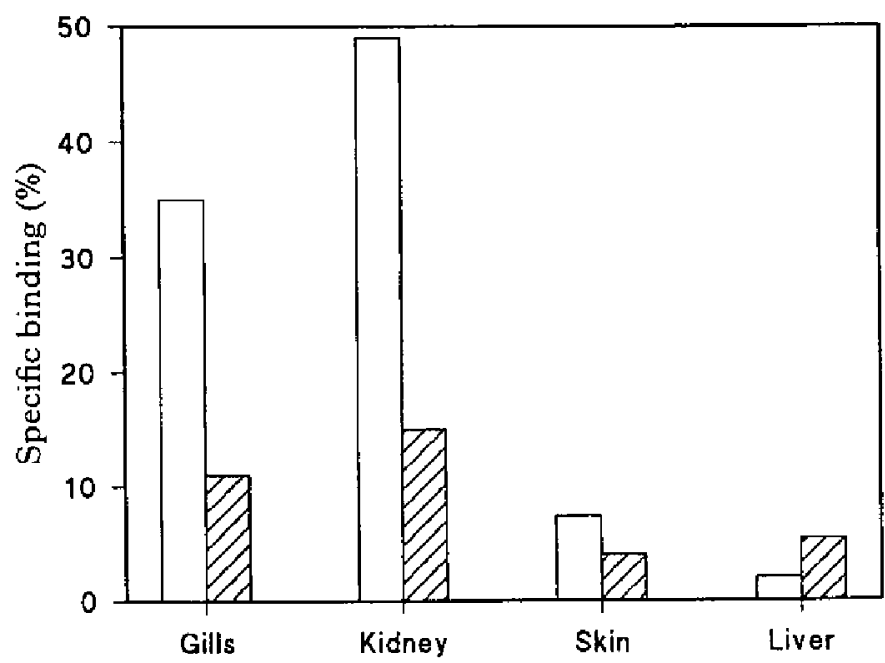

FIGURE 1. Specifc binding $(\mathrm{B} / \mathrm{T} \times 100$, where $\mathrm{B}=$ specific binding and $\mathrm{T}=$ amount of radioactivity added to the tube) of ${ }^{125} \mathrm{I}$-labelled tiPRL (open bars) and ${ }^{125}$ I-labelled tiPRL $L_{I I}$ (hatched bars) to tilapia organs. Tissue preparations ( $200 \mathrm{mg}$ wet tissue per tube) were incubated as described in the Materials and Methods. Histograms are the means of duplicate determinations.

\section{Membrane preparation and incubation conditions}

For both kidney and gill membranes, specific binding was pH-dependent, binding being highest in the pH range from 6.5 to 8 (data not shown). Studies were performed at $\mathrm{pH} 7 \cdot 5$, a value yielding the highest ratio of specific to non-specific binding.

The effect of changing the $\mathrm{MgCl}_{2}$ and $\mathrm{CaCl}_{2}$ concentrations was also investigated for gill membranes. For this organ, low concentrations of $\mathrm{MgCl}_{2}$ (1.5 mM) and $\mathrm{CaCl}_{2}(1.5 \mathrm{~mm}$ ) were required (data not shown). For kidney preparations, only effects of $\mathrm{MgCl}_{2}$ were investigated, and in this study the highest binding was obtained at a low $\mathrm{MgCl}_{2}$ concentration (1.5 mM) (data not shown). For both kidney and gill membranes, $\mathrm{NaCl}(150 \mathrm{mM})$ in the incubation medium caused a $50 \%$ decrease in specific tiPRL I $_{\text {and tiPRL }}$ binding. Thus no $\mathrm{NaCl}$ was added to the incubation medium.

\section{Saturation experiments}

Specific binding of the tiPRLs to gill membranes increased linearly with the membrane concentration in the ranges $10-150 \mu \mathrm{g}$ protein/tube for tiPRL $\mathrm{I}_{\mathrm{I}}$ and $10-250 \mu \mathrm{g}$ protein/tube for tiPRL $\mathrm{II}$. We were thus able to increase specific binding to $40-45 \%$ and 25-30\% respectively (Fig, 2a). Likewise, in kidney preparations specific binding of both PRLs increased linearly as the membrane concentration 

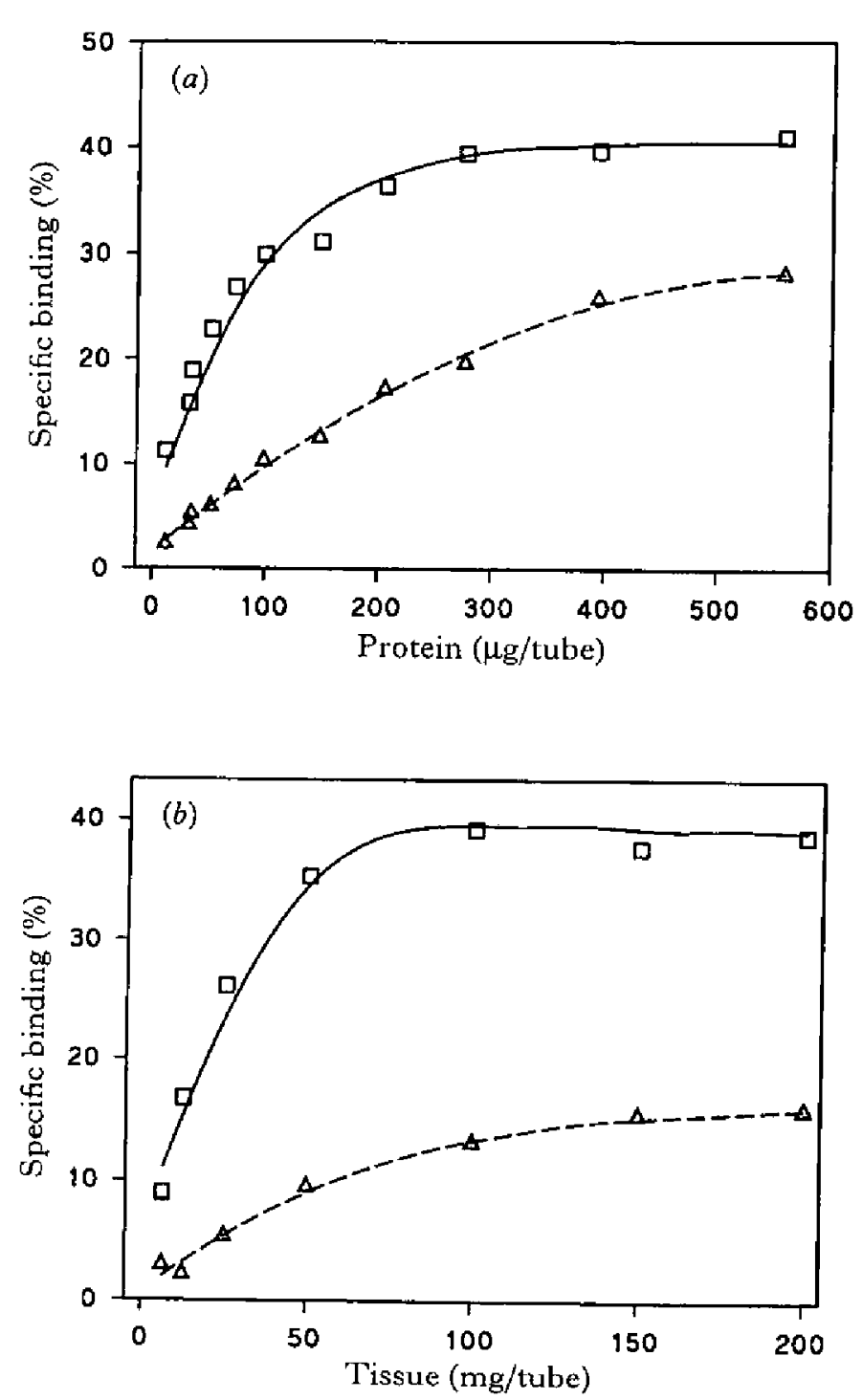

FIGURE 2. (a) Specific binding (B/T $\times 100$, where $\mathrm{B}=$ specific binding and $\mathrm{T}=$ amount of radioactivity added to the tube) of ${ }^{125}$ I-labelled tiPRL $(\square)$ and ${ }^{125} \mathrm{I}_{\text {-labelled tiPRL }}(\triangle)$ to gill membranes as a function of protein concentration $(\mu \mathrm{g} / \mathrm{tube})$. (b) Specific binding $(\mathrm{B} / \mathrm{T} \times 100)$ of ${ }^{325}$ I-labelled tiPRL $(\square)$ and ${ }^{125} \mathrm{I}_{\text {-labelled tiPRL }}(\triangle)$ to kidney membrane preparations as a function of kidney tissue concentration (mg/tube). Tissue preparations were incubated as described in the Materials and Methods. Values are means of duplicate determinations.

increased from 10 to $50 \mathrm{mg}$ tissue/tube, reaching $40-45 \%$ for tiPRL $\mathrm{I}_{\mathrm{I}}$ and $10-15 \%$ for tiPRL II (Fig. $2 b)$.

\section{Association studies}

Figure $3 a$ shows the effects of incubation time and temperature on specific binding to gill membranes of tiPRL $L_{1}$. With tiPRL $L_{1}$, apparent equilibrium was reached after $40 \mathrm{~h}$ at $4{ }^{\circ} \mathrm{C}, 20 \mathrm{~h}$ at $12^{\circ} \mathrm{C}$, or $8 \mathrm{~h}$ at $25^{\circ} \mathrm{C}$. Thereafter, the specific binding remained stable for over $40 \mathrm{~h}$ at $4{ }^{\circ} \mathrm{C}$ and $4 \mathrm{~h}$ at $12^{\circ} \mathrm{C}$, but decreased rapidly at $25^{\circ} \mathrm{C}$. A similar picture was observed with tiPRL $\mathrm{Il}_{\mathrm{I}}$, although at $4{ }^{\circ} \mathrm{C}$ the specific binding never quite reached the levels obtained at 12 and $25^{\circ} \mathrm{C}$ (data not shown).

Figure $3 b$ shows the effects of incubation time and temperature on the specific binding of tiPRL to kidney membranes. Equilibrium was reached after 20,20 and $50 \mathrm{~h}$ at 18,12 and $4{ }^{\circ} \mathrm{C}$ respectively. Thereafter, specific binding remained stable until the end of the experiment $(100 \mathrm{~h})$ except at $18{ }^{\circ} \mathrm{C}$, at which temperature it decreased slowly after $50 \mathrm{~h}$.

\section{Specificity experiments}

The hormonal specificity of tiPRL $_{I}$ and $t_{i P R L_{I I}}$ binding was further analysed. With gill membrane preparations, binding of ${ }^{125} \mathrm{I}$-labelled tiPRL $\mathrm{I}_{\mathrm{I}}$ or ${ }^{125}$ I-labelled tiPRL ${ }_{I I}$ was inhibited when the homologous unlabelled tiPRL was added. This effect increased with the concentration of unlabelled hormone (Fig. 4). Interestingly, native tiPRL ${ }_{\mathrm{I}}$ and tiPRL $_{\text {II }}$ purified from pituitary tissues exhibited the same potency as recombinant tiPRL $L_{1}$ and tiPRL in inhibiting the binding of ${ }^{125} \mathrm{I}$-labelled tiPRL $\mathrm{I}_{\mathrm{I}}$ to gill membrane preparations (Fig. 5). Other hormones were also tested. The results of these experiments, shown in Fig. 4, clearly show that: (1) tiPRL $_{I}$ was the best competitor for both ${ }^{125}{ }^{2}$ labelled tiPRL ${ }_{\mathrm{I}}$ (Fig. $4 a$ ) and ${ }^{125} \mathrm{I}_{\text {-labelled tiPRL }}$ (Fig. 4b), unlabelled tiPRL ${ }_{\text {II }}$ being 8-10 times less potent (calculated at 50\% displacement); (2) oPRL could also compete for binding, but it was 30 times less potent than tiPRL $\mathrm{I}_{\mathrm{I}}$ and 5 times less potent than tiPRL $\mathrm{II}_{\mathrm{II}}$ (calculated at $50 \%$ displacement); (3) tiGH and oGH did not significantly displace ${ }^{125} \mathrm{I}$-labelled tiPRL $_{1}$ or ${ }^{125} \mathrm{I}_{\text {-labelled tiPRL }}$ from their binding sites on gill membranes.

A corresponding study conducted with kidney membranes yielded results similar to the above.

\section{Scatchard analysis}

The characteristics of tiPRL $L_{I}$ and tiPRL $L_{I I}$ binding to gill and kidney membrane preparations were determined by Scatchard analysis of the saturation curves. As shown in Figs 6 and 7, binding of either tiPRL was a saturable process. The Scatchard plots reveal a single class of high affinity binding site in both gill and kidney tissues. This single class of receptors, moreover, exhibited a higher affinity for tiPRL $_{\mathrm{I}}$ than for tiPRL $\mathrm{III}_{\mathrm{I}}$ in gill. This difference was clearer when kidney membranes were used 

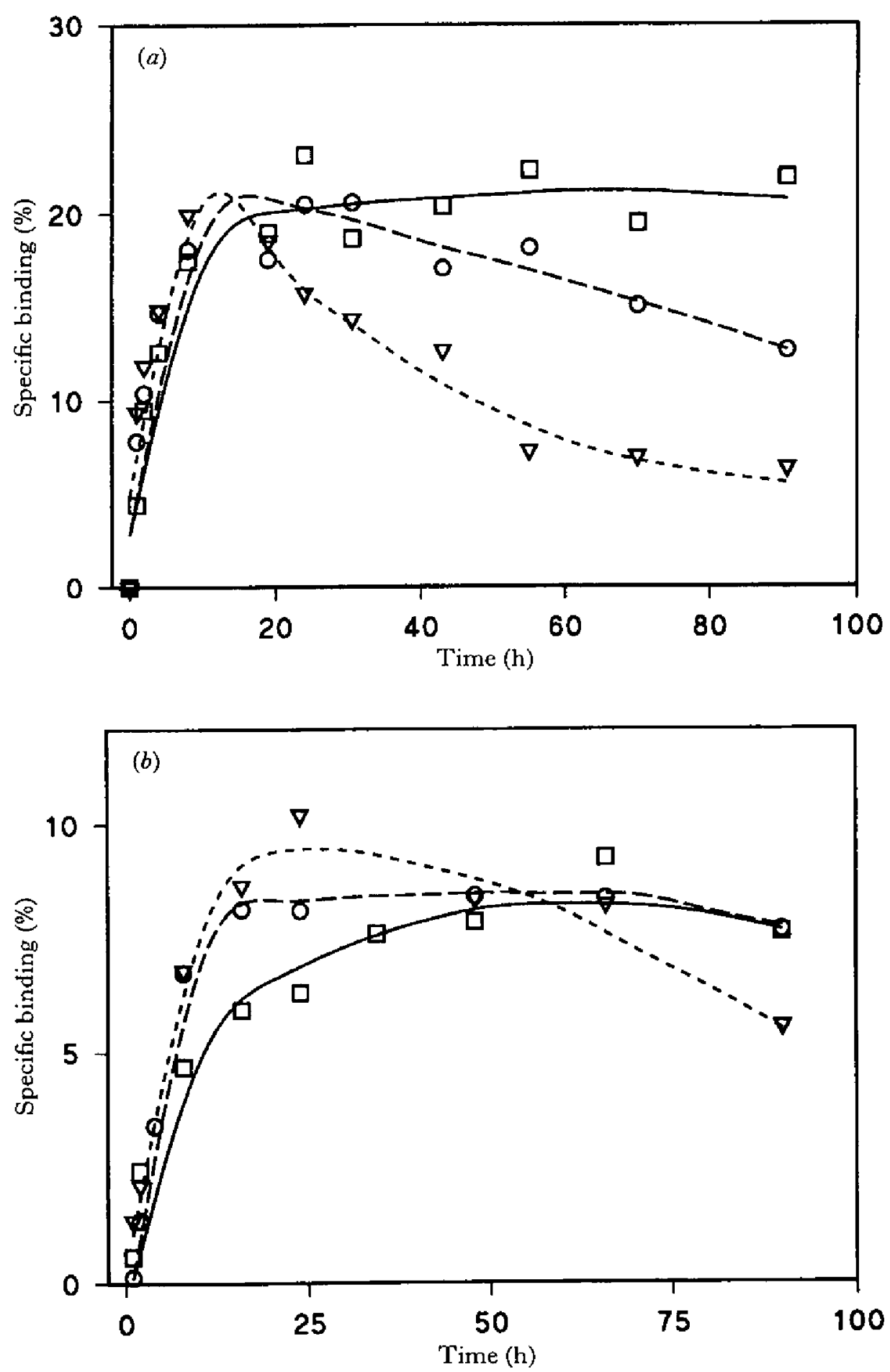

FIGURE 3. (a) Effects of time and temperature $\left(\square, 4{ }^{\circ} \mathrm{C} ; 0,12^{\circ} \mathrm{C} ; \nabla, 25^{\circ} \mathrm{C}\right)$ on specific binding $(B / T \times 100$, where $B=$ specific binding and $T=$ amount of radioactivity added to the tube) of ${ }^{125}{ }^{1-l a b e l l e d ~ t i P R I ~}{ }_{I}$ to gill membrane preparations ( $40 \mu \mathrm{g}$ protein/tube). (b) Effects of time and temperature ( $\square$, $\left.4{ }^{\circ} \mathrm{C} ; \mathrm{O}, 12{ }^{\circ} \mathrm{C} ; \nabla, 18^{\circ} \mathrm{C}\right)$ on specific binding $(\mathrm{B} / \mathrm{T} \times 100)$ of ${ }^{125} \mathrm{I}$-labelled tiPRI $_{1}$ to kidney membrane preparations (15 $\mathrm{mg}$ wet tissue/tube). Values are means of duplicate determinations.

(Table 1). In both tissues, the binding capacity for tiPRL $_{\mathrm{I}}$ was about twice that obtained for tiPRL $\mathrm{L}_{\mathrm{II}}$, although these differences are not significant due to the variability of the measurements (Table 1). Moreover, gill and kidney binding capacities were of similar magnitudes when the $\mathrm{B}_{\max }$ values were 

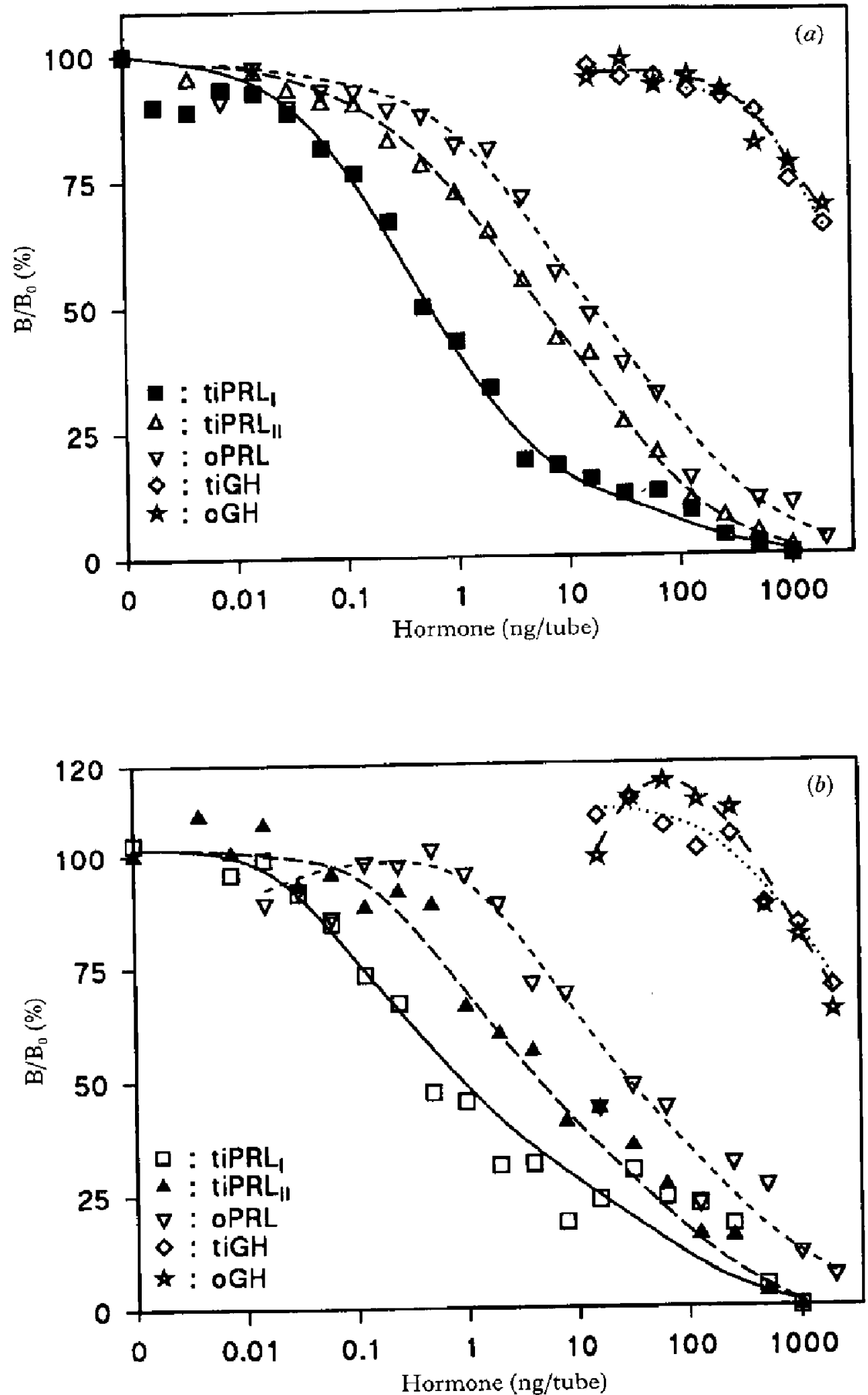

FIGURE 4. Competition curves for (a) ${ }^{125} \mathrm{I}$-labelled tiPRL $\mathbf{1}$ and $(b)$ ${ }^{125} \mathrm{I}_{\text {-labelled tiPRI }}{ }_{\mathrm{II}}$ binding to gill membrane preparations $(80 \mu \mathrm{g}$ protein/tube), obtained by increasing the concentration (expressed in $\mathrm{ng} / \mathrm{tube}$ ) of various hormone preparations. Binding is expressed as a ratio of the ${ }^{125} \mathrm{I}$-labelled tiPRL specific binding in the presence of competition (B) to the ${ }^{125} \mathrm{I}$-labelled tiPRL specific binding in absence of competition $\left(\mathrm{B}_{0}\right)$, multiplied by 100 to obtain a percentage. Tissue preparations were incubated as described in the Materials and Methods. Values are means of duplicate determinations. 


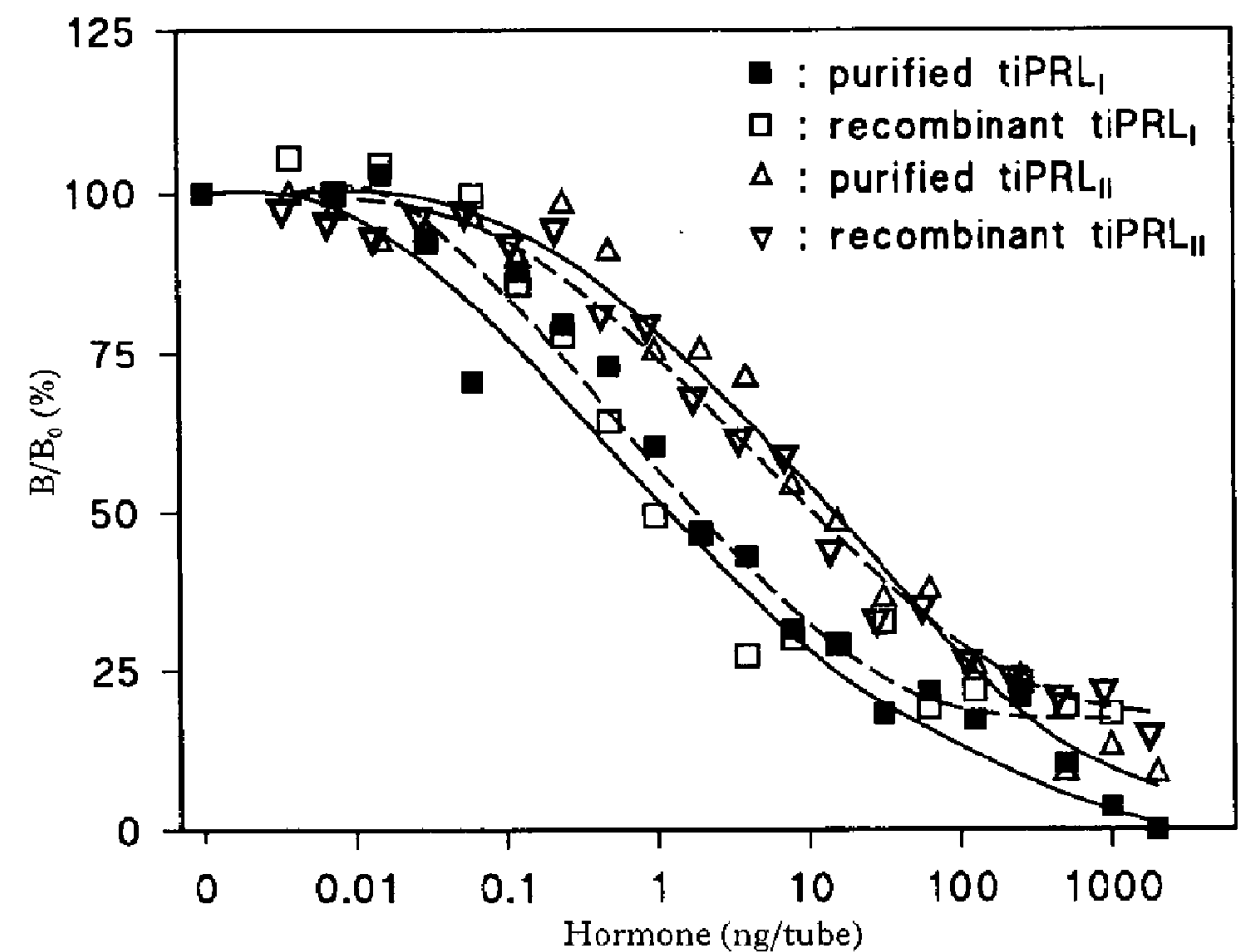

FIGURE 5. Competition curves for ${ }^{325} \mathrm{I}$-labelled tiPRL $\mathrm{L}_{\mathrm{J}}$ binding to gill membrane preparations ( $130 \mu \mathrm{g}$ protein/tube), obtatned by adding increasing concentrations (expressed in $\mathrm{ng} /$ tube) of various hormone preparations. Binding is expressed as the ratio of ${ }^{125} \mathrm{I}$-labelled tiPRL $\mathrm{L}_{\mathrm{I}}$ specific binding in the presence of competition (B) to ${ }^{125} \mathrm{I}$-labelled tiPR $\mathrm{L}_{\mathrm{I}}$ specific binding in the absence of competition $\left(\mathrm{B}_{0}\right)$, multiplied by 100 to obtain a percentage. Tissue preparations were incubated as described in the Materials and Methods. Values are means of duplicate determinations.

expressed per unit weight of initial fresh tissue (data not shown).

\section{DISCUSSION}

The present study is the first to present a complete characterization of tiPRL receptors in lower vertebrates, based on the use of homologous recombinant tiPRLs. Our results clearly establish the presence of one class of high affinity tiPRL receptors in the gill and kidney of Oreochromis niloticus. tiPRL $L_{I}$ binds to these receptors with a higher affinity than tiPRL $L_{I I}$.

The two recombinant tiPRLs previously prepared and characterized by Swennen et al. (1991) compete with ${ }^{125}$ I-labelled tiPRL $L_{I}$ as effectively as do native tiPRLs for binding to gill receptors. This confirms the finding of Swennen et al. (1991) that the biological activities of the recombinant tiPRLs are intact, thus validating the use of these recombinant hormones to characterize tiPRL receptors in Oreochromis niloticus gill and kidney.
A preliminary analysis of specific binding in various organs indicated that gill and kidney seem to be the tissues showing the highest tiPRL receptor contents. This suggests that both tissues are physiological targets for the direct action of PRL, which is in agreement with the much studied osmoregulatory role of PRL in fish (Clarke \& Bern, 1980). Surprisingly, the liver showed low specific binding for either tiPRL, although we tried fresh and frozen tissues and different protocols for membrane preparation (B. Auperin \& P. Prunet, unpublished results).

Use of recombinant tiPRL preparations allowed us to obtain high levels for specific binding of tiPRL $_{1}$ and tiPRL 11 to both kidney and gill membrane preparations. It also appears that specific binding is increased by the use of low Tris- $\mathrm{HCl}$ and divalent cation concentrations, an observation already reported by Yao et al. (1991) for trout GH receptors. Attempts to desaturate the gill and kidney membrane preparations by $\mathrm{MgCl}_{2}$ treatment (Kelly et al. 1979) failed to improve the specific binding of either tiPRL (data not shown). However, collecting tissues from fish transferred for $36-48 \mathrm{~h}$ 

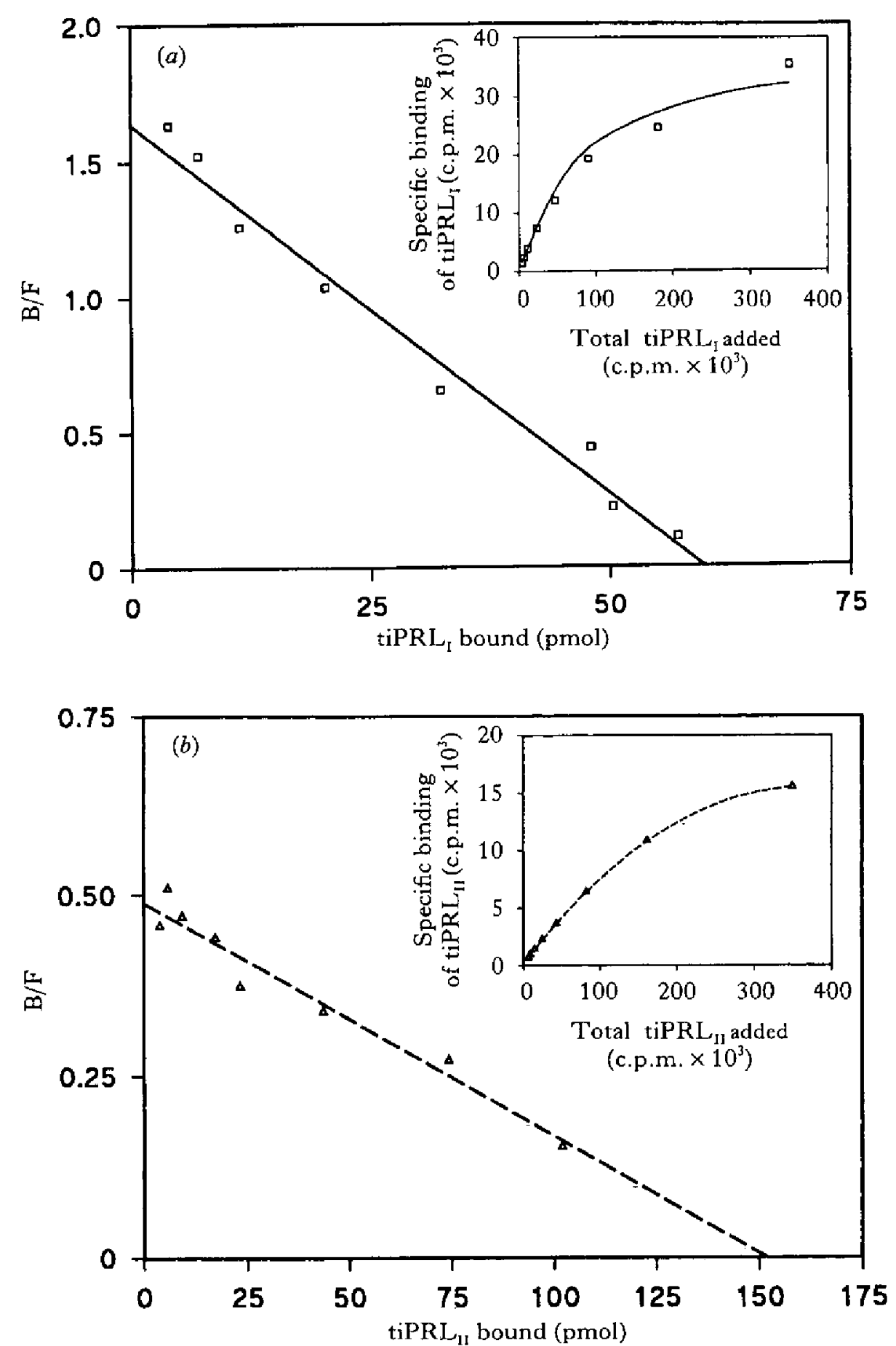

FIGURE 6. Scatchard plots of specific $(a){ }^{125}$ I-labelled tiPRL $L_{\mathrm{I}}$ and $(b)$ ${ }^{125}$ I-labelled tiPRL $L_{1 I}$ binding to gill membrane preparations. The insets show the effect of increasing concentrations of ${ }^{125}$ I-labelled tiPRL $_{1}$ or ${ }^{125} \mathrm{I}$-labelled tiPRL $_{1 \mathrm{I}}$ on specific binding, and were used for the Scatchard analysis. $\mathrm{B} / \mathrm{F}$, ratio of bound to free hormone. Tissue preparations were incubated as described in the Materials and Methods. Values are means of duplicate determinations.

to brackish water increased the specific binding of both PRLs to gill and kidney preparations. 'This was also shown by Auperin et al. (1994b) who demonstrated an increase in the number and affinity of gill PRL receptors after transfer from fresh to brackish water. 

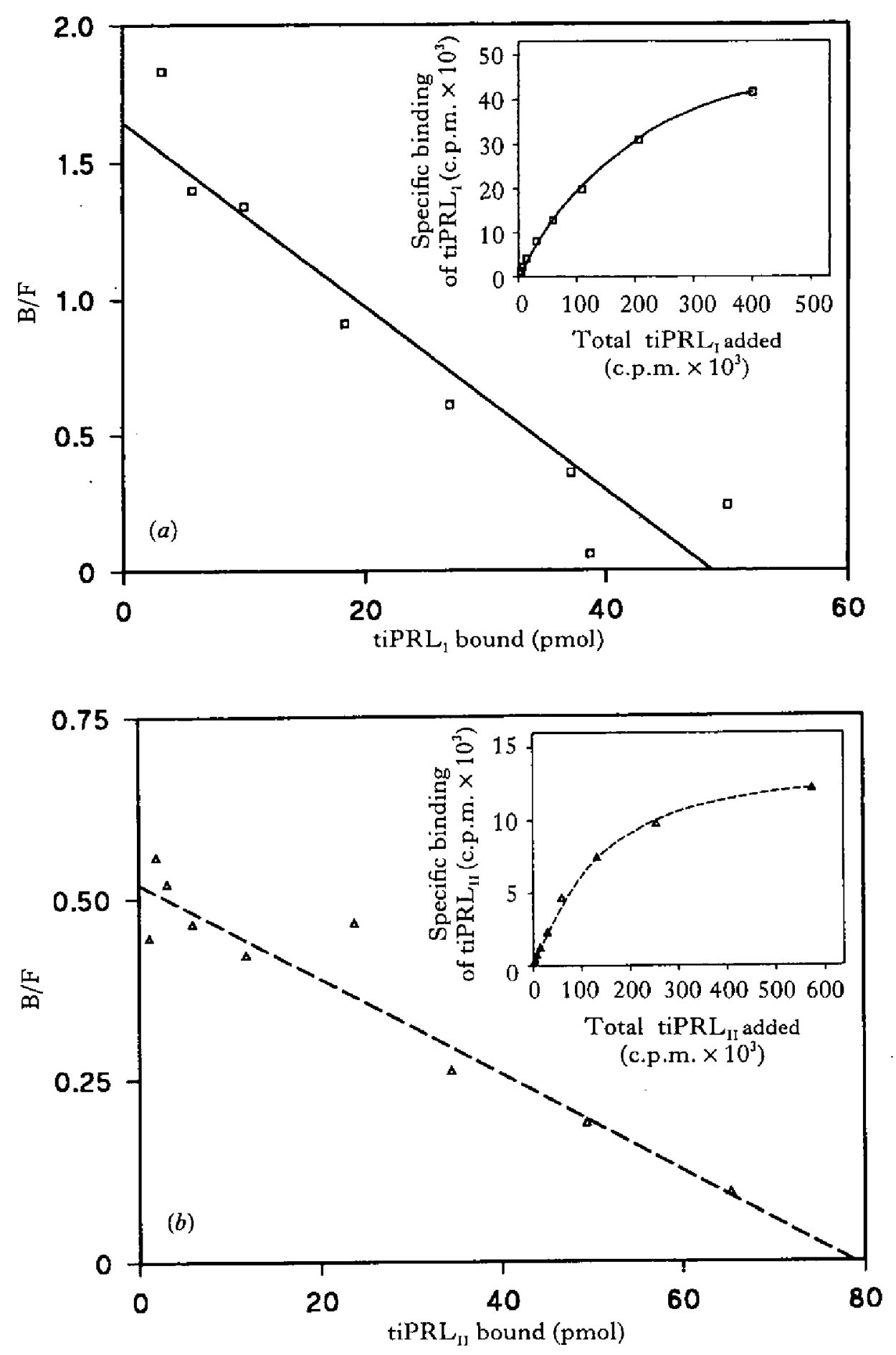

FIGURE 7. Scatchard plots of specific $(a){ }^{125} \mathrm{I}_{\text {-labelled tiPRL, }}$ and $(b)$

${ }^{125} \mathrm{I}_{\text {-labelled tiPRL }}$ binding to kidney membrane preparations. The insets show the effect of increasing concentrations of ${ }^{125}{ }^{1}$-labelled tiPRL $L_{1}$ or ${ }^{125} \mathrm{I}_{\text {-labelled tiPRL }}$ on specific binding, and were used for the Scatchard analysis. $\mathrm{B} / \mathrm{F}$, ratio of bound to free hormone. Tissue preparations were incubated as described in the Materials and Methods. Values are means of duplicate determinations.

The specific binding characteristics (saturability and high affinity) of the two tiPRLs fit the criteria for receptors. Scatchard analysis revealed a single class of tiPRL receptor, whichever tiPRL was used as a ligand. The affinity constants were always significantly higher for tiPRL $\mathrm{I}_{\mathrm{I}}$ than for tiPRL $\mathrm{II}_{\mathrm{II}}$ in both gill 
TABLE 1. $K_{\mathrm{a}}$ and $\mathrm{B}_{\max }$ values for ${ }^{125} \mathrm{~J}$-labelled tiPRL $\mathrm{I}_{\mathrm{I}}$ and ${ }^{\mathrm{j} 25} \mathrm{I}$-labelled tiPRL ${ }_{I I}$ in gill and kidney membrane preparations. Tissue preparations were incubated as described in the Materials and Methods. Values are the means \pm s.e.M. of three separate determinations

\begin{tabular}{|c|c|c|c|}
\hline Tissue & Ligand & $K_{\mathrm{a}}\left(\times 10^{10}\right)($ per $\mathrm{M})$ & $\mathbf{B}_{\max }(\mathrm{fmol} / \mathrm{mg})$ \\
\hline Gills $(n=3)$ & $\begin{array}{l}\text { tiPRL }_{1} \\
\text { tiPRL }_{11}\end{array}$ & $\begin{array}{l}2 \cdot 9 \pm 0 \cdot 2 \\
1 \cdot 9 \pm 0 \cdot 6^{*}\end{array}$ & $\begin{array}{l}61 \cdot 7 \pm 4 \cdot 4 \\
34 \cdot 8 \pm 12 \cdot 9\end{array}$ \\
\hline Kidney $(n=3)$ & $\begin{array}{l}\text { tiPRL } \\
\text { tiPRL }_{1}\end{array}$ & $\begin{array}{l}2 \cdot 3 \pm 1 \cdot 1 \\
0 \cdot 5 \pm 0 \cdot 16^{*}\end{array}$ & $\begin{array}{l}24 \cdot 5 \pm 11 \cdot 7 \\
13 \cdot 5 \pm 1 \cdot 0\end{array}$ \\
\hline
\end{tabular}

* $P<0.05$ compared with $K_{\mathrm{n}}$ for tiPRL $\mathrm{L}_{1}$ in the same tissue (Mann-Whitney test).

and kidney tissues. This result is confirmed by the specificity curves, in which tiPRL ${ }_{\mathbf{I}}$ always appeared 8-10 times more potent than tiPRL $L_{11}$ in competing for both gill and kidney binding sites, whichever tiPRL was used as a ligand. Moreover, both tiPRLs totally displaced both tiPRL ligands from their binding sites, a result which further supports our hypothesis of a unique PRL receptor in these organs. However, we cannot be certain that our experimental conditions are adequate for characterizing another tiPRL receptor in gill and kidney, and that Scatchard analysis would necessarily reveal a second binding site. This would be the case particularly if the second receptor was in low concentration with a binding affinity close to the values reported for the previous PRL receptor. The initial cloning of the cDNA for the rat PRL receptor in the liver led to the identification of multiple forms of PRL receptor in mammals and human (Kelly et al. 1991). A similar approach should be developed to determine whether one or several PRL receptor forms are present in tilapia gill and kidney.

Interestingly, recombinant tiGH and oGH did not significantly displace either the ${ }^{125} \mathrm{I}$-labelled tiPRL $L_{I}$ or the ${ }^{125}$ I-labelled tiPRL ${ }_{I 1}$ ligand from gill or kidney preparations. This indicates that, although PRLs and GHs have structural and evolutionary similarities, PRL receptors in these fish tissues do not bind homologous or mammalian GH. The results of previous studies in which oPRL was used as a ligand (Edery et al. 1984; Dauder et al. 1990) have already suggested the presence of PRLbinding sites in the gill and kidney of Oreochromis mossambicus. Yet with this heterologous system $\left({ }^{125} \mathrm{I}-\right.$ labelled oPRL displaced by tiPRL $L_{1}$ or tiPRL 1 I $)$ it was not possible to clearly characterize the tiPRL receptors, as specific ligand binding was always low $(2-7 \%)$. Furthermore, tiGH displaces ${ }^{125}$ I-labelled oPRL bound to liver membranes with potencies of 0.8 and 5.5 compared with tiPRL $L_{I}$ and tiPRL $_{I I}$ respectively (Dauder et al. 1990). It thus appears that oPRL can also recognize tiGH receptors, as sug- gested by Nicoll (1982) and Dauder et al. (1990). This makes it hard to compare these studies (Edery et al. 1984; Dauder et al. 1990) with our results.

The characteristics of the tiPRL receptor we have uncovered are very similar to those described for PRL receptors in mammalian liver and mammary gland, especially as regards their specificity (Shiu \& Friesen, 1974; Djiane et al. 1977; Sakai et al. 1985). Measurements of the apparent $K_{\mathrm{a}}$ values for tiPRL in both tissues $\left(2-3 \times 10^{10}\right.$ per $\left.M\right)$ indicate a receptor of very high affinity. These values are about 10 -fold higher than those currently reported for liver and mammary gland PRL receptors in mammals. However, similar high values for $K_{\mathrm{a}}$ have recently been reported for the PRL receptor in the adrenal cortex of the pig (Klemcke et al. 1989). It should be also noted that the higher $K_{\text {a }}$ values obtained using tiPRL $_{\mathrm{I}}$ are quite compatible with the low concentrations of plasma $P R L_{I}$ reported in fresh wateradapted tilapia (Auperin et al. 1994a).

It was also interesting to compare the characteristics of tiPRL receptors in gill and kidney. As regards their specificity, the receptors present in the two tissues exhibit similar ranges of activity, tiPRL $L_{I}$ being the most potent ligand, followed by tiPRL $\mathrm{L}_{\mathrm{II}}$, oPRL, and, as weak competitors, tiGH and oGH. The $K_{\mathrm{a}}$ values obtained for tiPRL $\mathrm{I}$ binding were similar in the two tissues; so were the binding capacities expressed per unit weight of initial tissue. The $K_{\mathrm{a}}$ values calculated for tiPRL $\mathrm{II}_{\text {II }}$ binding differed significantly, however, between the two tissues. This warrants a more complete characterization of the tiPRL receptor using molecular biological techniques in order to determine whether the receptors are identical in gill and kidney.

The presence of a single tiPRL receptor class in gill and kidney, with a higher affinity for tiPRL than for tiPRL ${ }_{1 I}$, does not explain, or at least not simply, all the results obtained in vivo in tiPRLtreated fish. It can explain why tiPRL $L_{1}$ is more potent than tiPRL $\mathrm{II}_{\mathrm{I}}$ in its ability to maintain plasma $\mathrm{Na}^{+}$and $\mathrm{Cl}^{-}$levels in fish adapted to brackish 
water, but it does not explain why this effect is dose-related for tiPRL, but not for tiPRL 11 (Auperin et al. 1994a). Indeed, the binding affinity of oPRL for the tiPRL receptor characterized here is lower than that of either tiPRL, yet when oPRL is injected into fish adapted to brackish water, its $\mathrm{Na}^{+}$and $\mathrm{Cl}^{-}$-retaining effects are dose-related (Auperin et al. 1994a); thus, the absence of dose-related effects after tiPRL ${ }_{I I}$ treatment cannot be explained by a lower affinity of tiPRL ${ }_{1 I}$ for kidney or gill PRL receptors. Moreover, tiPRL ${ }_{I}$ and tiPRL ${ }_{\text {II }}$ show similar abilities to maintain plasma $\mathrm{Na}^{+}$levels in hypophysectomized fish reared in fresh water, but they affect $\mathrm{Cl}^{-}$levels differently (B. Auperin, F. Rentier-Delrue, J. A. Martial \& P. Prunet, unpublished observations). These results clearly show that the two tiPRL forms have different osmoregulatory effects. At the present time, it is difficult to speculate upon the mechanisms that mediate these different actions, a question which clearly deserves further study.

\section{ACKNOWLEDGEMENTS}

oPRL and oGH were gifts from the Pituitary Hormone Distribution Program of the NIDDK.

\section{REFERENCES}

Auperin, B., Rentier-Delrue, F., Martial, J. A. \& Prunet, P. (1994a). Evidence that two tilapia (Oreochromis niloticus) prolactins have different osmoregulatory functions during adaptation to a hyperosmotic environment. Fournal of Molecular Endocrinology 12, 13-24.

Auperin, B., Rentiet-Delrue, F., Martial, J. A. \& Prunet, P. (1994b). Regulation of gill tiPRL receptors in tilapia (Oreochromis miloticus) after a salinity change or hypophysectomy. Fournal of Endocrinology. (In Press.)

Clarke, W. C. \& Bern, H. A. (1980). Comparative endocrinology of prolactin. In Hormonal Proteins and Peptides, vol. VIII, pp. 105-197. Ed. C. H. Li. New York: Academic Press.

Dauder, S., Young, G., Hass, L. \& Bern, H. A. (1990). Prolactin receptors in liver, kidney, and gill of the tilapia (Oreochromis mossambicus): characterization and effect of salinity on specific binding of iodinated ovine prolactin. General and Comparative Endocrinology 77, 368-377.

Djiane, J., Durand, P. \& Kelly, P. A. (1977), Evolution of prolactin receptors in rabbit mammary gland during pregnancy and lactation. Endocrinology 100, 1348-1356.

Edery, M., Young, G., Bern, H. A. \& Steiny, S. (1984). Prolactin receptors in tilapia (Sarotherodon mossambicus) tissues: binding studies using ${ }^{125} \mathrm{I}$-labeled ovine prolactin. General and Comparative Endocrinology 56, 19-23.

Garnier, J. (1980). Principes de base pour la caractérisation des récepteurs hormonaux des membranes cellulaires. Application aux méthodes de dosage. Journal de Physiologie 76, 189-197.

Greenwood, F. C., Hunter, W. M. \& Glover, J. S. (1963). The preparation of ${ }^{31}$ I labelled human $\mathrm{GH}$ of high specific radioativity, Biochemical Fournal 89, 114-123.
Hirano, 'T., Ogasawara, T., Bolton, J. P., Collie, N. L., Hagesawara, S. \& Iwata, M. (1986). Osmoregulatory role of prolactin in lower vertebrates. In Comparative Physiology of Environmental Adaptations, vol. 1, pp. 112-124. Eds R. Kirsch \& B. Lalhou. Basel: S. Karger.

Kelly, P. A., Djiane, J., Postel-Vinay, M.-C. \& Edery, M (1991). The prolactin/growth hormone receptor family. Endocrine Reviews 12, 235-251.

Kelly, P. A., Leblanc, G. \& Djiane, J. (1979). Estimation of total prolactin-binding sites after in vitro desaturation. Endocrinology 104, 1631-1638.

Klemcke, H. G., Pond, W. G. \& Nienaber, J. A. (1989). Porcine adrenal prolactin receptors: characterization, changes during neonatal development and effects of hypoprolactinemia. Comparative Biochemistry and Physiology 92A, 197-206.

Lowry, O. H., Rosebrough, N. J., Fart, A. L. \& Randall, R. J. (1951). Protein measurement with the Folin phenol reagent. fournal of Biological Chemistry 193, 265-275.

Martal, J. (1972). Détermination radioimmunologique des hormones de croissance ovine et bovine: étude des conditions d'iodation et obtention d'une hormone somatotrope radioiodée sans prolactine contaminante. Comptes Rendus de l'Académie des Sciences 274, 2893-2896.

Nicoll, C. S. (1982). Prolactin and growth hormone: specialists on the one hand and mutual mimics on the other. Perspectives in Biology and Medicine 25, 369-381.

Prunet, P. \& Auperin, B. (1994). Prolactin receptors. In Fish Physiology, Molecular Aspects of Hormonal Regulation in Fish, vol. XIII. Eds N. Sherwood \& C. L. Hew. San Diego: Academic Press. (In Press.)

Rentier-Delrue, F., Swennen, D., Prunet, P., Lion, M. \& Martial, J. A. (1989). Tilapia prolactin: molecular cloning of two cDNAs and expression in Escherichia coli. DNA 8, 261-270.

Sakai, S., Katoh, M., Berthon, P. \& Kelly, P. A. (1985). Charaterization of prolactin receptors in pig mammary gland. Biochemical Fournal 224, 911-922.

Scatchard, G. (1949). The attraction of proteins for small molecules and ions. Annals of the New York Academy of Sciences 51, 660-673.

Shiu, R. P. C. \& Friesen, H. G. (1974). Properties of a prolactin receptor from rabbit mammary gland. Biochemical fournal 140, 301-311.

Specker, J. L., King, D. S., Nishioka, R. S., Shirahata, K, Yamaguchi, K. \& Bern, H. A. (1985). Isolation and partial characterization of a pair of prolactins released in vitro by the pituitary of a cichlid fish, Oreochromis mossambicus. Proceedings of the National Academy of Sciences of the U.S.A. 82, 5490-5494.

Swennen, D., Renticr-Delrue, F., Auperin, B., Prunet, P., Flik, G., Wendelaar Bonga, S. E, Lion, M. \& Martial, J. A. (1991). Production and purification of biologically active recombinant tilapia (Oreochromis niloticus) prolactins. Fournal of Endocrinology 131, 219-227.

Yamaguchi, K., Specker, J. L., King, D. S., Yokoo, Y., Nishioka, R. S., Hirano, T. \& Bern, H. A. (1988). Complete amino acid sequence of a pair of fish (tilapia) prolactins, tPRL $_{177}$ and PRL $_{188}$. Foternal of Biological Chemistry 263, 9113-9121.

Yao, K., Niu, P. D., Le Gac, F, \& Le Bail, P. Y. (1991). Presence of specific growth hormone binding sites in rainbow trout (Oncorhynchus mykiss) tissues: characterization of the hepatic receptor. General and Comparative Endocrinology 81 , $72-82$.

REVISED MANUSCIPT RECEIVED 9 June 1994 